\title{
스리랑카 개발포럼 2005 결과보고
}

스리랑카 개발포럼이 스리랑카 Kumaratunga 대통 령, Rajapakse 수상, 해외 50개국 150여 명의 대표 및 스리랑카의 각계 고위인사들이 참석한 가운데 2005년 5월 16 17일간 스리랑카 Kandy에서 개최 되었는 바, 주요 내용은 아래와 같음.

\section{I . 핵심내용}

\section{1. 주스리랑카 대사의 발언 요지}

무스리랑카 대사는 금번 회의 개최가 지난 4 개월 여에 걸친 스리랑카의 지진해일피해 구호 · 복구 활동을 점검하고 향후 중장기 개발 프로젝트를 논 의한다는 점에서 매우 시의적절하다고 평가함.

ㅁ주스리랑카 대사는 한국 정부는 현금(60만불)과 현물(70만불 상당)을 포함한 130 만불의 무상원조 를 기히 전달하였고, 향후 3 개년에 걸쳐 무상원조 1,370 만불을 포함한 3,500 만불 규모의 구체적인
사업을 현재 스리랑카 정부와 협의하고 있는 바, 조만간 결정될 것이며 그 외에도 약 1,000 여 명으 로 구성된 30 여 한국의 $\mathrm{NGO}$ 들이 7백만불 상당의 구호 - 복구 지원을 기히 시행하였고, 대한적십자 사가 향후 3 개년에 걸쳐 450 만불 상당의 재난구 호센터 설립을 추진하고 있다고 우리의 지진해일 피해 지원현황을 설명함.

무스리랑카 대사는 또한 스리랑카 정부가 북동부 지역의 지진해일피해 추진 공동조정기구(Joint Mechanism) 설치를 추진하고 있는 데 대해 지지 를 표명함으로써 원조공여국 및 국제기구들의 동 기구 설치에 대한 전폭적인 지지 움직임에 동참함. ㅁ주스리랑카 대사는 스리랑카의 중장기 경제정책 틀 (framework) 관련, 우리의 경험에 비추어 경제 정책 방향에 대한 국민적 합의 및 강력한 리더쉽과 농촌개혁에 있어서 정신적 - 사회심리적 중요성을 강조하고 향후 5 개년간 6 8\%의 고율성장을 지속 하기 위해서는 수출지향정책을 후퇴시키지 말 것 
을 권고함.

\section{2. 스리랑카측 의의}

ㅁ 스리랑카의 복구 · 재건 사업 추진 및 경제운영 능 력에 대한 신뢰성을 제고시킴으로써 원조공여국 및 국제기구들로부터 20 억불 지진해일피해 원조 약속액의 이행을 촉진할 수 있는 계기를 마련함.

ㅁ공동조정기구 추진에 대해 원조공여국 및 국제 기구로부터 전폭적인 지지를 확보함으로써 Kumaratunga 대통령의 동 조정기구 추진이 탄 력을 받게 될 것으로 보임.

\section{3. 원조공여국측 의의}

ㅁ국정최고 책임자인 Kumaratunga 대통령으로부 터 향후 평화과정의 기초가 될 '공동조정기구' 추 진의 강한 의지를 확인할 수 있었다는 점이 금번 회의의 최대 수확임.

마울러 지진해일피해 복구 - 재건사업의 '시행 (implementation)' 의 중요성을 강조하고 스리랑 카측에 원조자금 배분상의 공평성, 투명성, 책임 성에 대한 인식을 제고시킴.

\section{II. 주요내용}

\section{1. 회의 개요}

\section{1)동 회의 참석자:해외 50 개국 150 여 명}

ㅁ정부대표 참석국가:우리나라를 비롯, 미국, $\mathrm{EU}$, 캐나다, 중국, 일본, 인도, 호주 등 23 개국
ㅁㄱㄱㄱ제기구:UN, 세계은행, 아시아개발은행, $\mathrm{UNDP}, \mathrm{UNICEF}, \mathrm{OPEC}$, 아랍경제 개발을 위한 쿠웨이트 펀드(DFAED), 사우디개발펀드(SFD) 등 17 개 기관

므리랑카측:Kumaratunga 대통령, Rajapakse 수상, Amunugama 재무·기획부장관, Kadirgamar 외교부장관 등 관계부처 장 - 차관, 국회의원 등 각계 고위인사 다수 참석

\section{2) 회의 내용}

ㅁ개회식

뭊제 1 :지진해일피해 복구 · 재건 (주제발표 및 토론)

ㅁ주제 2:경제성장 및 빈곤완화(주제발표 및 토론) ㅁ주제 3 : 평화협상과정 및 향후 방향 (주제발표 및 토론)

\section{2. 회의 결과}

1) 개회식 연설요지

\section{가. Chandrika Kumaratunga 대통령}

ㅁ Kumaratunga 대통령은 어떠한 위험과 어려움을 무릅쓰고라도 LTTE와 협력하여 북동부 지역의 지진해일 피해지역 재건을 위한 공동조정기구 (Joint Mechanism)를 진전시키기로 결정하였다 고 강한 의지를 표명함.

Kumaratunga 대통령은 LTTE측이 주권국가의 틀 내에서 싱할라 및 무슬림 커뮤니티와 동일조건 으로 일을 하려하는 것은 최초의 일이라고 언급하 고 정부는 다음 수주 내에 공동조정기구 추진에 합 
의하는 결실을 얻게 될 것이라고 전망함.

ㅁ 동 대통령은 스리랑카의 다수는 정부의 입장을 지 지하고 있으며 국제사회의 지지가 필요하다고 협 조를 요청함.

ㅁ동 대통령은 공동조정기구가 평화과정의 직접적 인 일환은 아니나 종족갈등의 영구적 해결방안을 강구할 수 있는 여러가지 가능성을 제시해주게 될 것이라는 확신을 밝힘.

\section{나. Sarath Amunugama 재무 - 기획부장관}

ㅁ환영사를 통해 금번회의 주제별 요지를 다음과 같 이 언급함.

-지진해일피해 복구 - 재건 관련 향후 $3 \sim 5$ 년간 약 20 억불이 소요될 것으로 추정되며 이와 비슷 한 액수를 국제사회로부터 지원 약속 받음.

- 경제성장 및 빈곤완화 관련 향후 5년간 6 8\%의 고성장을 이룩하기 위해 전략기업, 인프라, 교 육, 보건 및 환경부문 등에 개혁을 추진하고 국 내생산성과 투자율을 제고시킬 것임.

- 경제성장을 위해서는 평화과정이 필수요건이며 다행히 주요정당들이 예외 없이 전쟁보다는 평 화로의 진전 가능성을 믿고 있음.

\section{다. Praful Patel 세계은행 부총재}

미진해일피해 복구 - 재건의 향후과제는 '시행 (implementation)' 이라고 전제하고 구체적인 시 행 관련 다음 4 가지 과제를 지적함.

-이재민에 대한 주택공급관련 택지의 확보 및 배 분, 완충지대(buffer zone) 기준의 적용문제 등
-지역주민과의 협의주선

(consultation arrangement)

-중앙정부와 지방정부 차원의 조정

(coordination)

-자금의 적절한 관리를 위한 책임성 확보문제

Patel 부총재는 또한 스리랑카의 평화과정 관련 지난 3년간의 '정전협정' 유지를 평가하고 북동부 지역의 지진해일피해 복구 - 재건 지원을 시행할 공동조정기구(Joint Mechanism) 설치를 위한 당 사자들의 노력에 대한 지지를 표명함.

2) 〈주제 1〉 지진해일피해 복구 · 재건

\section{가. 국제사회 지원현황}

(1) 개요

ㅁㅇㅇ국정부, 국제기구 및 $\mathrm{NGO}$ 를 포함한 스리랑카 에 대한 총지원 약속액은 약 22.3 억불이며, 그중 7.4 억불은 외국정부, 6.3 억불은 국제기구, 8.5 억 불은 NGO 지원 약속액임.

ㅁ 지원약속액의 $90 \%$ 이상은 무상원조임.

(2)외국정부 지원

ㅁㅜㅜㅇㅛ 지원국가는 일본(181백만불), 프랑스(104백 만불), 캐나다(84백만불), 독일(81백만불), $\mathrm{EU}$ (75백만불), 이태리(69백만불), 미국(65백만불), 한국(35백만불), 스페인(25백만불), 인도(23백만 불)순임.

ㅁ국가별 중점지원대상 분야를 살펴보면, 일본의 경우 무상원조는 수산, 도로 및 교량, 교육 분야 에 유상원조는 중소기업 지원, 전력, 도로 및 교 량, 수도공급 및 하수처리 등에 중점을 두고 있 
음. 프랑스는 도로 및 교량, 수도공급 및 하수처

리, 주택건설에, 독일은 주택, 수도공급, 전력에, $\mathrm{EU}$ 는 도로 및 교량에, 이태리는 교육에, 미국은 도로 및 교량, 주택, 중소기업 지원에 각각 중점을 두고 있는 것으로 나타남.

(3)국제기구지원

무죵 국제기구별 지원약속액은 $\mathrm{ADB}$ (157백만불), 세계은행(150백만불), $\mathrm{EIB}(90$ 백만불), UN 기구 (69백만불), IFAD(35백만불), $\mathrm{WFP}(25$ 백만불), $\mathrm{UNICEF}$ (21백만불)순임.

뭉ㅇ점지원 대상 분야로 $\mathrm{ADB}$ 는 도로 및 교량, 생계 지원, 수도공급 및 하수처리, 수산분야에, 세계은 행은 주택, 도로 및 교량, 수도공급 및 하수처리, 생계지원, 교육, 수산분야에, $\mathrm{EIB}$ 는 중소기업 지 원에 각각 중점을 두고 있음.

(4) $\mathrm{NGO}$ 지원

ㅁ NGO들의 지원 약속 액은 2005년 3월 현재 약 8.5 억불이며 그 중 약 57 백만불을 확약함.

(5) 채무면제 및 상환유예

면재까지 약 42.5 백만불의 부채가 면제 또는 상환 연기되었으며, 그밖에 한국의 6 백만불을 포함하여 금년중 295백만불이 상환 유예될 것으로 예상됨.

\section{나. 지진해일피해 재건사업 시행원칙}

므르ㄹㅏㅏㅇㅋㅏ 정부는 모든 지진해일피해 재건사업은 다음과 같은 원칙(Guiding Principles)에 기초를 두고 시행할 것이라고 밝힘.

- 공평성 확보

- 무차별 원칙(성별, 정치, 종교, 종족등)에 입각한
지원 수요 평가

- 지방행정기관에 대한 권한 부여

-관계자간의 협의 및 의사소통 원활화

-투명성 확보 및 부패방지

-책임성 확보 및 관리철저

-불평등 및 미래 취약성 방지

- 조정의 원활화 및 효율성 제고

\section{다. 토론 요지}

무스리랑카 대사는 금번 회의 개최가 지난 4 개월 여에 걸친 스리랑카의 지진해일피해 구호 · 복구 활동을 점검하고 향후 중장기 개발 프로젝트를 논 의한다는 점에서 매우 시의적절하다고 평가함.

무스리랑카 대사는 한국 정부는 현금(60만불)과 현물(70만불 상당)을 포함한 130만불의 무상원조 를 기히 전달하였고, 향후 3 개년에 걸쳐 무상원조 1,370 만불을 포함한 3,500 만불 규모의 구체적인 사업을 현재 스리랑카 정부와 협의하고 있는 바, 조만간 결정될 것이며 그 외에도 약 1,000 여 명으 로 구성된 30 여 한국의 $\mathrm{NGO}$ 들이 7백만불 상당의 구호 - 복구 지원을 기히 시행하였고, 대한적십자 사가 향후 3 개년에 걸쳐 450 만불 상당의 재난구 호센터 설립을 추진하고 있다고 우리의 지진해일 피해 지원현황을 설명함.

무스리랑카 대사는 또한 스리랑카 정부가 북동부 지역의 지진해일피해 추진 공동조정기구(Joint Mechanism) 설치를 추진하고 있는 데 대해 지지 를 표명함으로써 원조공여국 및 국제기구들의 동 기구 설치에 대한 전폭적인 지지 움직임에 동참함. 
대부분의 원조공여국 대표들은 북동부지역 지진 해일피해 복구 - 재건사업 추진을 위한 공동조정 기구의 설치가 공평한 지원배분 및 신뢰형성을 위 해 필요하다고 언급하고 스리랑카 정부의 추진노 력에 전폭적인 지지를 표명함.

ㅁ원조공여국 대표들은 또한 복구재건사업에 있어 서 시행의 중요성을 강조하고 책임성과 투명성 확 보, 참여자들간 및 중앙정부와 지방정부간의 조정 의 원활화, 무차별 지원, 지방차원의 사업시행능 력 구축 등이 필요함을 지적함.

므ㄱㅏㅏㅏㅇㅔ EU 회원국들을 중심으로 ‘완충지대' 설 정기준의 적용, 피해복구 및 재건사업 시행에 따른 환경 및 사회적 영향 등에 관심을 나타냄.

\section{3) 〈주제 2〉경제성장과 빈곤완화}

\section{가. 경제성장 및 빈곤완화를 위한 정책틀(Framework)}

ㅁ 경제성장율 목표를 현재의 5\% 수준에서 6 8\% 수 준으로 상향 조정

미역적 불균형 성장 완화 및 빈곤층을 위한 성장전 략 추진을 통한 개발효과의 확산

ㅁㅜㅜㅈㅏ 비중을 $\mathrm{GDP}$ 의 $30 \%$ 이상 제고시키기 위해 국제경쟁력 향상 및 투자환경 개선

ㅁㄱㄱㄱ가의 대외보유자산 확충

ㅁ상기 중장기 정책목표를 달성하기 위해 주요 부문 에 대한 개혁 실시

\section{나. 토론 요지}

무스리랑카 대사는 우리의 경험에 비추어 경제정 책 방향에 대한 국민적 합의 및 강력한 정치적 리
더십과 새마을운동의 예를 들어 농촌개혁에 있어 서 정신적 - 사회심리적 중요성을 강조하고 향후 5 개년간 6 8\%의 고율성장을 지속하기 위해서는 수출지향정책을 후퇴시키지 말 것을 권고함.

ㅁ원조공여국 대표들은 중장기 종합적인 정책틀 (Framework)을 설정한 데 대해 평가하는 한편, 개혁의 추진방법, 시행에 대한 신뢰성 제고, 정책 의 일관성 확보 등의 중요성을 지적함.

\section{4)〈주제 3〉평화협상 과정 및 향후 방향}

\section{가. 공동조정기구 추진 의의}

ㅁ 공동조정기구 설치 추진에 대한 여론조사 결과 응 답자의 $65.6 \%$ 로부터 지지를 받고 있는 것으로 나 타났다고 발표함.

-응답자 소속별 지지율:싱할라 $50.9 \%$, 타밀 93.3\%, 무슬림 72.9\%, LTTE $100 \%$

ㅁ현재 논의중인 공동조정기구(안)은 적용지역 및 기 간상에 제한을 두고 있으며, 지진해일피해 복구 · 재건 업무수행을 위한 행정기구에 지나지 않을 뿐 평화협상 과정의 일환이 아님.

ㅁ LTTE측이 공동조정기구에 참여하는 것이 향후 동 조직을 제도정치권으로 흡수하는 계기가 될 수 있을 것으로 기대함.

\section{나. 토론 요지}

ㅁ원조공여국 대표들은 대체적으로 공동조정기구 설치 추진에 관한 Kumaratunga 대통령의 의지 에 대한 지지를 재확인함. 


\section{III. 관찰 및 평가}

ㅁ현재까지는 해외에서 세계은행 주관 하에 회의를 개최함으로써 스리랑카가 피동적인 입장에서 참 가했으나 금번 회의는 스리랑카 국내의 전통적인 옛 고도에서 스리랑카 주관 하에 회의를 개최함으 로써 스리랑카가 자주적인 입장에서 회의를 주도 하였다는 이미지를 부각시킴.

Kumaratunga 대통령은 원고에 의존하지 않고 장시간 차분하게 지진해일피해 복구 - 재건 사업 의 과제를 조목조목 상세하게 설명하였을 뿐만 아 니라 특히 북동부지역의 재건사업 시행을 위한 공 동조정기구 추진 배경, 설치안 및 본인의 강한 추 진 의지를 명확하게 밝힘으로써 회의 참석 대표들 로부터 전폭적인 지지를 얻었으며, 이는 원조공여 국 및 국제기구의 지원약속액 이행에 긍정적으로 작용할 것임.
모탄 공동조정기구 추진에 대해 원조공여국 및 국 제기구로부터 전폭적인 지지를 확보함으로써 Kumaratunga 대통령의 동 조정기구 추진이 탄 력을 받게 될 것으로 관측됨.

ㅁ원 조공 여국측은 국 정최 고책 임 자 인 Kumaratunga 대통령으로부터 향후 평화과정의 기초가 될 '공동조정기구' 추진의 강한 의지를 확 인하고 지진해일피해 복구 - 재건사업 시행과정상 원조자금 배분의 공평성, 투명성, 책임성 제고에 대한 스리랑카의 관심을 환기시킴.

ㅁ우리 대표단은 토론과정에의 적극적인 참여를 통 해 우리 정부 및 민간단체들의 지진해일피해 지원 현황과 지원정책 방향을 소상하게 설명함으로써 우리의 역할에 대한 국제적인 이해를 제고하고 스 리랑카와의 협력관계 강화에 기여함.

[자료:주스리랑카 대사관] 